\title{
LEARNING QUALITY MANAGEMENT AT SMP DARUL ARQAM GOMBARA MAKASSAR
}

\author{
Martini $^{1}$ \\ Abdul Rahman Mus ${ }^{2}$ \\ Ahmad Hakim ${ }^{3}$ \\ Akhmad Syahid ${ }^{4}$ \\ Universitas Muslim Indonesia, Indonesia ${ }^{1,2,3,4}$ \\ martinitini9@ gmail.com ${ }^{1}$
}

\begin{abstract}
This study examined in depth the management of learning quality by looking at the four management components, namely Planning, Organizing, Actuating, and Controlling (POAC) at SMP Darul Arqam Gombara Makassar. The research uses a qualitative phenomenological approach, with the type of research being a multi-site study. Data collection techniques through questionnaires, interviews, observation and documentation. The data were analyzed using an interactive analysis model consisting of data collection, data reduction, data presentation, verification, and conclusions. This study indicates that learning quality management at SMP Darul Arqam Makassar is implemented through four steps. First, learning planning according to Process Standards with innovative and accelerated curriculum content with the demands of the current education "market" and designed in an integrated manner between academic and non-academic activities based on progress and superiority. Second, learning organizations with well-placed resources integrated academic and non-academic schedules and internal institutional support for human resource development. Third; implementation of learning supported by competent and professional educators; adequate learning media; innovation in facilitating active, creative, fun learning; and an objective and accountable scoring system. Fourth, learning supervision by an objective and transparent performance appraisal system, internal and external supervisors with integrity.
\end{abstract}

Keywords: Quality Management; SMP Darul Arqam Gombara

\section{BACKGROUND}

The study of learning quality is linked to the objective conditions of all important aspects of Education. The state of the teaching personnel, the curriculum and teaching materials employed, the students, and the means of supporting the learning infrastructure are all aspects of Education. It is also linked to the parameters of the learning environment. For example, in terms of teaching staff quality, statutory requirements established in Permendikbud Number 16 of 2007 stipulate that teachers must have particular academic level certifications. This standard requires a four-level diploma (D4) or an undergraduate (S1) study program in a relevant field. These minimum requirements must be obtained from an accredited study program.

These qualification standards apply nationally and mechanistically to encourage teacher quality as the main educators in the learning process. Teachers play an essential role in translating and transmitting the standard content of the curriculum that has been designed. All learning activities make the teacher the central instrument that builds the dynamics of interactive learning with students. Teachers must be actively involved in 
developing students' thinking through the use of varied teaching techniques.

Learning can be made more engaging by employing a variety of strategies. The National Education Standards (SNP) also state that the learning process in academic units must be interactive, inspiring, fun, and challenging in order to motivate students to participate actively and provide enough space for the initiative, creativity, and abilities based on talent, interests, and physical and psychological development.

Muljono ${ }^{1}$ elaborated on the importance of numerous factors in determining the quality of learning. First, high-quality learning requires conformity that is linked to student characteristics. Agreement leads to harmony with society's and individuals' ambitions in this environment. Learning should be tailored to the community's needs as well as the surrounding environment. Furthermore, learning must always follow current demands and numerous theories and concepts, particularly the dynamics of new values that are continually growing in Education.

Second, quality learning must be appealing. There are a variety of intriguing learning indicators in this context, such as the distribution of easy-to-achieve and follow learning opportunities and instructional content that is easy to digest since it has been summarised in this way. Other signs include open options that anybody can obtain at any time and communications delivered at specific times and occasions. Appropriate, high reliability, particularly given the institution's and graduates' excellent performance, the diversity of sources, both purposely designed. Those are already available and may be picked and used for learning objectives, and an atmosphere that is intimate, warm and stimulates the formation of students' personalities.

Third, effective learning is frequently judged by goal achievement, but it can also be viewed as precision in managing a situation or "doing the right things." This understanding has systematic characteristics. It is carried out on a regular, consistent, or sequential basis through the stages of planning, development, implementation, assessment, and refinement, sensitivity to the need for learning tasks and learning needs, clarity of goals. Thus efforts can be gathered to achieve them (students, educators, society and government).

Fourth, learning must have efficiency, which can be interpreted as the equivalence between the time, cost, and energy used with the results obtained or can be said to be doing something right. Designing learning activities based on models related to students' interests, needs, and conditions is one of its qualities. Furthermore, neatly organizing learning and learning activities, for example, the environment or background is considered, utilization of various resources with a balanced division of tasks, as well as development and utilization of various learning resources as needed, utilization of shared learning resources, innovative efforts that are cost-effective, such as distance learning and open learning that do not require the construction of buildings, and hiring educators who are paid remuneration.

Fifth, Education must be productive. This is a state or process that allows obtaining better and more results. Learning productivity can mean: changing the learning process (from memorizing and remembering to analyzing and creating), adding input in the learning process (using various learning resources), increasing the intensity of student interaction with learning resources, or a combination of all three in learning activities. Learning to produce better quality, broader participation in Education, more graduates, graduates who are more valued by the community, and reduced dropout rates 2006. p. 29

${ }^{1}$ Muljono, P. 2006. Standar Proses Pembelajaran. Jakarta. Buletin BSNP Volume 1/No. 2/ Mei 
The external professionalism of a school institution can be said to describe the output and outcome of the school institution. The author's survey, interviews and initial observations of the school institution, namely SMP Darul Arqam Makassar, show that this school is an educational institution with learning services based on a pesantren environment. The results of the initial observations that the author made show that both Darul Arqam Middle School Makassar and Darul Istiqamah Middle School have produced many prominent graduates. These two schools grew up with the quality of learning services supported by an adequate Islamic boarding school environment. One indicator that can be seen is the productivity of learning which has given birth to many prominent alumni.

The curriculum of Darul Arqam Muhammadiyah Gombara Middle School combines the National curriculum (2013 Curriculum) and the curriculum in the education system at Muhammadiyah as characteristic called the ISMUBA curriculum (Al Islam Kemuhammadiyahan and Arabic). SMP Darul Arqam Muhammadiyah Gombara Makassar implements an integrated holistic system. Holistic means relating to the whole system as a whole rather than just a collection of parts, while integrated means to combine (combine to become a unified whole).

The activities that support the learning process, which is also an advantage over this school, are Tahfidzul Qur'an (at least 3 juz from grades VII-IX), the art of reading the Qur'an, Arabic club (al-lughatul Arabiyah), English (Speaking English), group Youth Science \& Journalism, Hizbul Wathan and Pencak Silat Tapak Suci, field trips (Field Studies), kemah and camping, autobond and traveling, study tours, preaching, MTQ Pelajar, and Gombara Cup.

The initial observations described above show the quantity and diversity of students, educators and education staff, curriculum, and infrastructure suggestions. This research is expected to provide adequate information for in-depth analysis of learning quality management by looking at the four management components: planning, organizing, actuating, and Controlling (POAC).

\section{THEORETICAL FRAMEWORK}

The definition of management in the context of Education, hereinafter referred to as education management according to Engkoswara and Komariah, is a structuring of the education sector which is carried out through planning, organizing, staffing, coaching, coordinating, communicating, motivating, budgeting, controlling, monitoring, evaluating, and reporting activities systematically to achieve quality educational goals. Usman asserted that learning management could be defined as planning, organizing, directing, and controlling learning resources to achieve learning objectives effectively, efficiently, independently, and accountably.

The substance of management is the management of all available resources for the achievement of the desired goals. Thus, management has a very strategic function in educational institutions, especially about managing the learning process. Notoatmodjo ${ }^{2}$ describes several management functions, as follows:

\footnotetext{
${ }^{2}$ Notoatmodjo, Soekidjo. 2009. Pengembangan Manajemen Sumber Daya Manusia. Jakarta: PT. Rineka Cipta. p.89.
} 


\section{A. Planning Function}

Planning is a process and a series of activities to set goals in advance at a certain time or period and the stages or steps that must be taken to achieve these goals. Feriyanto ${ }^{3}$ explained that planning is broadly defined as defining organizational goals, making strategies to achieve goals, and developing organizational work activity plans. Planning is the essential process of all management functions because, without planning, the other organizing, directing, and controlling functions cannot run.

Badaruddin ${ }^{4}$ explained several planning principles as follows.

1. Principle of contribution to objective. Every planning and all changes must be aimed at achieving goals.

2. Principle of efficiency of planning. An efficient plan if the plan in its implementation can achieve the goal with the smallest cost of money.

3. Principle of primary of planning. Planning is the main need of leaders and other functions, organizing, staffing, directing, controlling, evaluating, reporting. A person will not carry out other management functions without knowing the objectives and guidelines in carrying out policies.

4. Principle of pervasiveness of planning. The principle of equalization of planning plays an important role considering that leaders at high levels do a lot of planning and are responsible for the plan's success.

5. Principle of planning premise. Planning benchmarks are beneficial for applications because planning premises can indicate future events.

6. Principle of policy framework. This policy embodies work patterns, work procedures, and continuous work programs.

7. Principle of timing is a relatively short and precise time planning.

8. Principle of planning communication. Planning is well prepared and coordinated if everyone is responsible for his work and gets an adequate explanation of the field to be carried out.

9. Principle of alternative. Alternatives exist in each series of work, and planning includes selecting alternative sets in the implementation of work so that the goals that have been set are achieved.

10. Principle of limiting factor. In selecting alternatives, it must first be aimed at factors that are strategic and can help solve problems. Alternative principles and factor restrictions are absolute requirements in making decisions

11. The commitment principle. In selecting alternatives, it must first be at factors that are strategic and can help solve problems. Alternative principles and factor restrictions are absolute requirements in making decisions.

12. The principle of flexibility. Effective planning requires flexibility but does not mean changing goals.

13. The principle of navigation. Effective planning requires continuous observation of events that arise in its implementation to maintain goals.

14. The principle of strategic planning. Under certain conditions, the manager must choose the necessary actions to ensure the plan's implementation so that the objectives are achieved effectively.

${ }^{3}$ Feriyanto, dkk. 2015. Pengantar Manajemen (3 in 1) untuk Mahasiswa dan Umum. Yogyakarta: Mediatera. p. 13-14.

${ }^{4}$ Badaruddin. 2013. Dasar-Dasar Manajemen. Yogyakarta: Alfabeta. p. 55-57. 
Based on the previous description, it can be interpreted that planning is a process of thinking and determining activities for the future. Because planning is a process, several steps must be taken in making lesson plans, namely: (1) predicting the future; (2) analyzing the condition of educational institutions; (3) formulating learning objectives operationally; (4) collect data or information related to learning; (5) analyzing learning data or information; (6) formulating and determining alternative learning programs; (7) determine the estimated implementation of the learning program; and (8) develop a schedule for the implementation of the learning program. ${ }^{5}$

\section{B. Organizing Function}

Organizing is organizing and regulating people to be able to move as a unit according to the plans formulated towards achieving the stated goals. According to Engkoswara and Komariah, ${ }^{6}$ organizing function is the process of managing, allocating, and distributing work, authority, and resources among organizational members to achieve goals".

Organizing activities in learning management in schools is critical to make teachers and staff have a clear position in the structure and work through the selection, allocation, and distribution of professional work, so that the school's vision and mission can be achieved effectively efficiently.

Organizing a learning program can be done through the following procedures: (1) identifying the work or tasks that need to be done to achieve the learning objectives; (2) grouping similar tasks and functions; (3) give a specific name for each workgroup or task with a name that more or less describes their respective functions; (4) determine the people who will be appointed to complete each workgroup and task. If there are workgroups or specific tasks, they must be carried out by more than one person. Then one of them needs to be appointed as the person in charge; (5) distributing the facilities or equipment needed to complete the learning program; (6) establish work rules; and (7) establishing a working relationship. ${ }^{7}$

\section{Actuating Function}

Mobilization or implementation is the entire process of providing work motivation to subordinates in such a way that they can work sincerely to achieve organizational goals efficiently and effectively. According to Stoner, leading implementation is directing and influencing the work-related activities of group members or the entire organization. ${ }^{8}$

Leading schools place more emphasis on efforts to direct and motivate personnel to carry out their main tasks and roles well. Therefore, it takes leaders who meet leadership qualifications, especially in the context of improving the quality of Education with quality-based management. Siswanto (2012: 157) suggests the capabilities that a leader must possess, including: (1) a commendable character and personality; (2) high initiative; (3) desire to serve subordinates; (4) high intelligence; (5) future-oriented; (6) open and straightforward attitude; and (7) compelling voice-over.

Thus, it can be understood that actuating is managing the school organizational environment that involves the environment and other people in a suitable manner. Factors

\footnotetext{
${ }^{5}$ Bafadal, Ibrahim. 2009. Manajemen Peningkatan Mutu Sekolah Dasar; Dari Sentralisasi Menuju Desentralisasi. Jakarta: Bumi Aksara. p.39.

${ }^{6}$ Engkoswara dan Komariah. p.95.

${ }^{7}$ Bafadal, Ibrahim. p. 42.

${ }^{8}$ Engkoswara dan Komariah. p.95.
} 
guiding and giving warnings are supporting things for the success of the plan. If it is ignored, it will have an unfavourable influence on the continuity of a school organization. The process of leading in moving is giving orders, instructions, guidelines and advice, and communication skills. Leading is the essence of management that drives to achieve results with the principles of efficiency and good communication.

\section{Controlling Function}

The last function of management is supervision. According to Engkoswara and Komariah $^{9}$, supervision is a process to ensure that actual activities are following planned activities. Badaruddin stated that the control process is carried out in stages through the following steps; (a) determine the standards that will be used as the basis of control, (b) measure the implementation or results that have been achieved, (c) compare the implementation or results with the standards and determine deviations if any, and (d) take corrective actions, if there are deviations so that implementation and objectives are following the plan.

In carrying out control or supervision, there are at least four steps that must be taken, namely: (1) setting performance standards; (2) measure actual performance; (3) compare the actual performance with the performance standards that have been set, and (4) make performance improvements if it turns out that the actual performance is not under the standards. ${ }^{10}$

Learning is closely related to building good interactions between the two components, namely teachers and students. Good interaction can be described with a condition where the teacher can make students learn easily and are motivated by their own will to learn what is in the curriculum as their needs.

The basic concept of learning is formulated in Article 1 point 20 of Law Number 20 of 2003 concerning the National Education System. Learning is a process of interaction between students and educators and learning resources in a learning environment. From this understanding, it can be seen that the main characteristics of learning are initiation, facilitation, and improvement of students' learning process. This shows that the element of intentionality from outside individuals who carry out the teaching and learning process, in this case, educators individually or collectively in a system, is a common feature of the concept of learning.

Another characteristic of learning is that there is a deliberate, programmed interaction. The interaction occurs between students who study with their learning environment, both with educators, other students, media and or other learning resources. In addition, learning is the existence of components that are interrelated with each other. These components are objectives, materials, activities and evaluation of learning (Udin S. Winataputra, 2008: 21).

Meanwhile, Sobry Sutikno ${ }^{11}$ put forward the definition of learning, namely, all efforts made by the teacher so that the learning process occurs in students. Implicitly, there are activities to choose, define, and develop methods to achieve the desired learning outcomes in learning. Thus, in the following process, it can be seen that the success of a learning process cannot be separated from the participation and ability of a teacher in developing learning methods that aim at improving student learning in a teaching and learning process.

\footnotetext{
${ }^{9}$ Engkoswara dan Komariah. p.96.

${ }^{10}$ Bafadal, Ibrahim. p. 47.

${ }^{11}$ Sutikno, M. Sobry. 2009. Belajar dan Pembelajaran. Bandung: Prospect. p.32.
} 
Jamil Suprihatingrum stated that learning is a series of activities involving information and the environment that are planned to facilitate students in learning. The environment in question is the place where learning takes place and the methods, media, and equipment needed to convey information. Learning is an effort made by educators to help students receive the knowledge provided and help facilitate the achievement of learning objectives.

Meanwhile, according to Munandar in Suyono and Hariyanto ${ }^{12}$, learning is conditioned to encourage children's creativity as a whole, make students active, achieve learning goals effectively, and take place in pleasant conditions.

According to Trianto ${ }^{13}$, learning is a complex aspect of human activity that cannot be fully explained. Learning can be interpreted as a product of continuous interaction between development and life experience. Learning in a complex sense is a conscious effort from a teacher to teach his students (directing student interaction with other learning resources) in order to achieve the expected goals.

Meanwhile, according to Aqib ${ }^{14}$, the learning process is a systematic effort made by the teacher to run the learning process effectively and efficiently starting from planning, implementation, and evaluation. Thus, learning becomes a process carried out by individuals to obtain a change in overall behaviour due to the individual's interaction with his environment.

Based on the understanding of learning stated earlier, it can be concluded that learning is a process of interaction between students and teachers and their environment along with all other learning resources and facilities in order to achieve the desired goals to change the attitudes and mindsets of students.

\section{III.RESEARCH METHODS}

This study uses a qualitative phenomenological approach, with the type of research being a multi-site study. Data collection techniques through questionnaires, interviews, observation and documentation. The data were analyzed using an interactive analysis model consisting of data collection, data reduction, data presentation, verification, and conclusions. The data were analyzed in two stages, namely single site and cross-site analysis. The technique of checking the validity of the data is done through triangulation techniques of data sources and data collection methods.

\section{IV.FINDINGS AND DISCUSSION}

Good learning quality management determines the process of planning, organizing, implementing, and supervising. Still, it also needs to emphasize the importance of school principals, teachers, administration in managing quality educational institutions (schools). In the hopes of raising believers, pious people with decent personalities and accomplishments who can help strengthen the nation, religion, and state.

12 Suyono dan Hariyanto, 2011. Belajar dan Pembelajaran. Bandung: PT Remaja Rosdakarya. p.207.

13 Trianto. 2010. Model Pembelajaran Terpadu, Konsep, Strategi dan Implementasinya dalam KTSP. Jakarta: Bumi Aksara. p.17.

14 Aqib, Zainal. 2013. Model-model, Media dan Strategi Pembelajaran Kontekstual (Inovatif). Bandung: Yrama Widya. p. 66. 
As has been explained, to achieve quality student output, it is necessary to support quality learning management as well.

\section{A. Lesson Planning}

The planning design in learning quality management is based on the Regulation of the Minister of Education and Culture No. 22 of 2016. It concerning Standards for Primary and Secondary Education in Chapter III concerning learning planning that learning planning is designed in the form of curriculum devices, educational calendars, annual programs, semester programs, syllabus, material development analysis, and Lesson Plans (RPP) refers to Content Standard.

Based on the results of filling out questionnaires, observations and interviews with school principals, vice principals, administrative heads, and teachers, the items that describe learning planning at SMP Darul Arqam Makassar are explained as follows.

\section{Curriculum tools}

The curriculum set intended in this research is the Document 1 Kurikulum Tingkat Satuan Pendidikan (KTSP) Darul Arqam Junior High School (SMP) which also contains socialization of curriculum devices, school directions and policies contained in the KTSP, stakeholder involvement in the preparation of the KTSP, national content and schoolspecific content contained in the KTSP. Based on the results of the study that Darul Arqam Makassar Middle School has a 2013 curriculum, Al Islam Kemuhammadiyaan dan Bahasa Arab (SIMUBA) curriculum, curriculum guidelines for primary and secondary education units, local content guidelines, extracurricular activities guidelines, learning approaches, guidelines assessment of learning outcomes by educators, and guidance and counselling guidelines in primary and secondary Education.

While the basis for preparing school directions and policies contained in the KTSP, data sources and informants stated that Darul Arqam Middle School Makassar made the results of school self-evaluation (EDS), school exam achievements, and input from school stakeholders in this case the South Sulawesi Muhammadiyah Regional Leadership represented institutions of Pendidikan Dasar Menengah (Dikdasmen) and Lembaga Pengembangan Pesantren Muhammadiyah (LP2M), Muhammadiyah Regional Management, Muhammadiyah residents and sympathizers in the preparation of school directions and policies.

Regarding the availability of national content in the KTSP, data sources and informants stated that SMP Darul Arqam Makassar, in the preparation of the KTSP, has provided national content, especially in the subjects of Religious Education and Character Education, Citizenship Education (PKn), Indonesian Language, Mathematics, Natural Sciences (IPA). ), Social Sciences (IPS), English, Cultural Arts, PJOK, and Crafts. While the availability of typical school content in the KTSP, states that SMP Darul Arqam Makassar has local content or school content in the KTSP as a characteristic of the schools fostered by the Muhammadiyah association.

\section{The Academic calendar}

Based on the results of filling out the questionnaire, the data source stated that $75 \%$ of the teachers of SMP Darul Arqam Makassar compile an educational calendar, meaning that not all teachers have an academic calendar on their respective learning devices. The results of the interview with the Principal revealed that: 
"Indeed, the preparation of the educational calendar is usually carried out during the Workshop, which is jointly prepared and led by the Deputy Director for Education. The academic calendar that has been designed together is then distributed to each teacher to be asked to make revisions based on each teacher's learning schedule. It's just that there are teachers who are ignorant of this, arguing that there is already a cottage-level education calendar that regulates academic and non-academic activities including vacation time. Finally, they do not create a separate academic calendar for the disciplines in which they excel. "15

3. Annual program

Based on the results of filling out the questionnaire, data sources and informants stated that all teachers of SMP Darul Arqam Makassar had an annual program arranged in learning tools. Through the search for teacher learning tools documents, the researchers found the annual program that had been prepared by each teacher with reference to the Regulation of the Minister of Education and Culture No. 37 of 2018 concerning amendments to the Regulation of the Minister of Education and Culture Number 24 of 2016 concerning Core Competencies and Basic Competencies of 2013 Curriculum Lessons in Basic and Secondary Education.

\section{Semester program}

Based on the results of the study that researchers found the semester program that has been prepared by each teacher with reference to the Regulation of the Minister of Education and Culture No. 37 of 2018 concerning amendments to the Regulation of the Minister of Education and Culture Number 24 of 2016 concerning Core Competencies and Basic Competencies of 2013 Curriculum Lessons in Basic and Secondary Education.

5. Syllabus

When compiling the syllabus, it contains components including: basic competencies, learning materials, learning activities, assessments, time allocation, and learning resources.

\section{Material Development}

Based on the questionnaire results, 11 (eleven) people or $100 \%$ of data sources and informants gave different perceptions regarding the development of learning materials in the 2013 curriculum subjects whether they were following principles of quality development. These perceptions are classified as follows:

a) For the principle of increasing students' intelligence in the development of learning materials, all teachers perceive that more than $85 \%$ of the ten national content subjects have this principle.

b) For the principle of potential regional diversity in the development of learning materials, all teachers perceive that $51 \%-85 \%$ of 10 national content subjects have this principle.

c) For the principle of demands for regional, national, and work development in learning materials, all teachers perceive that $51 \%-85 \%$ of the ten federal content subjects have this principle.

\footnotetext{
${ }^{15}$ Interview with the Principal at SMP Darul Arqam Makassar. On July 10, 2021
} 
d) For the principle of science and technology demands and global developments in the development of learning materials, all teachers perceive that more than $85 \%$ of the ten national content subjects have this principle.

e) For the principle of national unity and nationality in the development of learning materials, all teachers give the perception that more than $85 \%$ of the ten federal content subjects have this principle.

As for the development of materials on specific school content, based on the results of filling out the questionnaire, there were 11 (eleven) people or $100 \%$ of data sources and informants who gave different perceptions regarding the development of learning materials in local subjects/school-specific subjects whether it was in accordance with the principles of quality development. These perceptions are classified as follows:

a) For the principle of increasing students' intelligence in the development of learning materials, all teachers give the perception that more than $85 \%$ of the eight local/school-specific content subjects have this principle.

b) For the principle of potential regional diversity in the development of learning materials, all teachers believed that more than $85 \%$ of the eight local/schoolspecific content subjects had this principle.

c) For the principle of demands for regional, national, and work development in the development of learning materials, all teachers perceive that $51 \%-85 \%$ of 8 local/school-specific content subjects have this principle.

d) For the principle of science and technology demands and global developments in learning materials, all teachers perceive that more than $85 \%$ of the eight local/school-specific content subjects have this principle.

e) For the principle of national unity and nationality in the development of learning materials, all teachers believed that more than $85 \%$ of the 8 local/school-specific content subjects had this principle.

7. Preparation of the lesson plan

In preparing the Lesson Plan (RPP) the Darul Arqam Makassar Middle School teacher arranges based on the subjects of each teacher and is made based on basic competencies or sub-themes in one meeting.

As for the contents of the Learning Implementation Plan (RPP), it states that the Darul Arqam Makassar Middle School teacher has prepared a lesson plan containing the elements regulated in the Minister of Education and Culture Regulation No. 22 of 2016 concerning the minimum components of the RPP which includes: (a) indicators which include indicators of attitudes, knowledge, and skills, (b) contextual learning materials according to local and global characteristics, (c) integrated learning materials with social, environmental, health issues at local, national, global levels, (d) activities learning applies various methodologies and approaches, (e) learning has involved the community, (f) learning uses various learning resources, $(\mathrm{g})$ learning uses various learning media, and $(\mathrm{h})$ assessment uses various assessment techniques according to three domains.

Even based on the results of document searches conducted by researchers, it was revealed that several teachers had compiled RPP using a simplification format according to the Circular Letter of the Minister of Education and Culture No. 14 year 2019 concerning the Simplified RPP Format, in which teachers can freely choose, create, use, and develop the 1-sheet RPP format as long as it follows the principles of being efficient, effective, and student-oriented. 
There are 9 (nine) stages of RPP preparation, namely: (a) syllabus review, (b) formulation of indicators for achieving KD at KI-1 (spiritual), KI-2 (social attitude), KI3 (knowledge), and KI-4 (skills), (c) development of learning materials, (d) description of learning activities in a more active form, (e) determination of time allocation for each meeting, (f) determining remedial learning strategies for students who have not completed and enrichment for students who have completed more quickly, (g) determine media, tools, and learning materials, (h) determine resource persons and learning resources, and (i) develop learning assessments.

It was just that based on interviews with the Principal and teachers, it was revealed that what often becomes a difficulty for teachers in the process of preparing lesson plans is the syllabus review.

\section{B. Learning organization}

The design of learning organization in learning quality management is based on the Regulation of the Minister of Education and Culture no. 22 of 2016 concerning Standards for Primary and Secondary Education in Chapter IV contains the requirements for the implementation of learning. Then the items that describe the organization of learning at SMP Darul Arqam Makassar are explained as follows.

1. Division of teaching tasks

In the division of tasks, there is a decree for the division of teaching tasks and other tasks for educators and education staff at SMP Darul Arqam Makassar issued by the Chairperson of the PWM South Sulawesi Primary and Secondary Education Council (Dikdasmen) at the suggestion of the Principal.

The results of the interview with the Principal stated that:

"The Headmaster proposed to the South Sulawesi PWM Educational Council about the division of teaching tasks, and the South Sulawesi PWM Educational Education Council Chair issued a decree. Usually, before entering the new school year, the decree has been delivered by the Executive Secretary of the South Sulawesi PWM Educational Council. The school principal then provides a copy of the decree to educators and education staff." 16

The same thing was conveyed by Nursyamsia, S.Pd. as Deputy Principal that:

"The division of teaching tasks and other tasks for educators and education personnel at SMP Darul Arqam Makassar is decided through a meeting with the Principal with the teacher council, and other education personnel at the Workshop at the end of the year. The results of the meeting then made a proposal by the Principal to the South Sulawesi PWM Educational Council Council to make a decree for the division of teaching tasks and other tasks. "17

2. Preparation of a schedule of learning activities

Effective learning activities are starting on Saturday-Thursday and Friday learning holidays at SMP Darul Arqam Makassar. The schedule for learning activities is prepared by the Principal facilitated by Deputy Mudir 1 for Education.

The results of the interview with the Principal stated that:

\footnotetext{
${ }^{16}$ Interview with the Principal at SMP Darul Arqam Makassar. On July 10, 2021

${ }^{17}$ Interview with the vice principal at SMP Darul Arqam Makassar. On July 17, 2021
} 
"The preparation of the learning activity schedule was facilitated by Deputy Mudir 1 for Education at Darul Arqam Islamic Boarding School because there are four academic units in this cottage, not only in junior high school but also teaching at MTS, MA, and SMK. Before the schedule of learning activities is arranged, the administrative staff distributes blanks to teachers containing the days and hours of learning. Then the teachers fill in the blocks of days and hours where they have time or opportunity. After that, the blanks are collected, and mapping and scheduling of learning activities is carried out." 18

Nursyamsia, S.Pd, conveyed the same thing. That:

"The preparation of the learning activity schedule is bottom-up, namely the proposed time and hours that fellow teachers have the opportunity because at this Islamic Boarding School there are 4 (four) educational units, so that the division of the learning activity schedule does not overlap, the preparation is facilitated by the vice of Mudir 1 for Education as the person responsible for coordinating cross-school interests in this Pondok." 19

3. Preparation of a schedule of repair and enrichment activities

The schedule for improvement or enrichment activities included in the preparation of the plan for learning activities at SMP Darul Arqam Makassar is one package with a program of learning activities that have been previously prepared by the Principal and facilitated by the vice of Mudir 1 for Education. The results of the interview with the Principal stated that:

"As for the remedial and enrichment activities schedule, we have compiled a package with a schedule of learning activities for 1 (one) year of learning. "20

Similar to what was conveyed by Nursyamsia, S.Pd., which states that:

"The repair or remedial and enrichment activities are in one package with a schedule of learning activities prepared for 1 (one) year of learning and have been discussed with the teacher council before the allocation of scheduling time." 21

4. Scheduling of extracurricular activities

The preparation of the schedule of academic activities at SMP Darul Arqam Makassar is also a package with the schedule of learning activities that have been previously prepared by the Principal and facilitated by the vice Mudir 1 for Education. The results of the interview with the Principal stated that:

"For the schedule of extracurricular activities, we have also arranged a package with a schedule of learning activities for 1 (one) year of learning by receiving input or input from the coaches of extracurricular activities. Our students' extracurricular activities are generally allocated in the afternoon and on learning holidays such as Fridays. "22

Nursyamsia, S.Pd. convey the same that:

\footnotetext{
${ }^{18}$ Interview with the Principal at SMP Darul Arqam Makassar. On July 10, 2021

${ }^{19}$ Interview with the teacher at SMP Darul Arqam Makassar. On July 17, 2021

${ }^{20}$ Interview with the Principal at SMP Darul Arqam Makassar. On July 10, 2021

${ }^{21}$ Interview with the teacher at SMP Darul Arqam Makassar. On July 17, 2021

${ }^{22}$ Interview with the Principal at SMP Darul Arqam Makassar. On July 10, 2021
} 
"The preparation of the schedule for extracurricular activities is also a package with a schedule of learning or academic activities. It was prepared for the next 1 (one) year of learning. In preparing the schedule for extracurricular activities, those who are required to provide the input or input are the extracurricular activity coaches. "23

5. Preparation of schedule of guidance and counselling activities

The guidance and counselling activities schedule is only separate from the previous 3 (three) activity schedules at SMP Darul Arqam Makassar. The guidance and counselling activities schedule turns out to be under the head of the boarding school (dormitory), who oversees the musyrif / musyrifah (student coaches in the dormitory) whose preparation is carried out by the Head of the Pondok and facilitated by Deputy Mudir 2 for Islamic Boarding School. The results of the interview with the Principal stated that:

"For the schedule of guidance and counselling activities, it is indeed under the responsibility of the Head of the Pondok who oversees the Musyrif / Musyrifah (student coaches in the dormitory) because they are the ones who spend more time interacting with the students so that they are more familiar with the problems and appropriate treatment in dealing with the problems faced by the students. This is also what makes the preparation of the schedule for guidance and counselling activities under the responsibility of them and their personnel." 24

The requirements for implementing the learning process that regulates the organization of study hours, study groups and class management are in Document 1 KTSP SMP Darul Arqam Makassar pages 163-164. It states that: (1) the time allocation of faceto-face learning hours for the Darul Arqam Middle School level is 40 minutes, and (2) the number of study groups at SMP Darul Arqam is six and the number of students in each study group is an average of 21 which is already relevant to the Regulation of the Minister of Education and Culture No. 22 of 2016 concerning Basic and Secondary Education Process Standards in Chapter IV which contains the requirements for the implementation of learning.

\section{Implementation of learning}

Based on the results of the study, the researchers described the items that the implementation of learning at SMP Darul Arqam Makassar explained as follows.

1. Opening of early semester learning

Teachers at the beginning of the semester to students at SMP Darul Arqam Makassar include: (a) competencies to be achieved, (b) what materials will be taught, (c) assignment designs that will be given for one semester, both individual and group assignments, (d) the assessment system that will be carried out by the teacher in assessing attitudes, knowledge and skills.

2. Learning opening activities

Early learning activities include what the teacher did when opening learning activities and activities carried out by students before or after the learning process. Only

${ }^{23}$ Interview with the teacher at SMP Darul Arqam Makassar. On July 17, 2021

${ }^{24}$ Interview with the Principal at SMP Darul Arqam Makassar. On July 10, 2021 
4 (four) aspects are conveyed by the teacher, including (a) asking to pray together, (b) discussing the competencies that have been learned and previously developed relating to the competencies to be studied and developed, (c) conveying the competencies to be achieved and their benefits in everyday life, and (d) conveying an outline of the scope of the material and activities to be carried out.

3. Core learning activities

The core activities in the learning process include learning activities carried out by teachers, and learning activities carried out by students. that there are 5 (aspects) that teachers "always" do in learning activities, namely: (a) encourage students to ask questions and express opinions, (b) check students' abilities, (c) provide feedback, (d) motivate students to conclude or try, and (e) encourage students to respect the opinions of others.

4. Media and learning facilities used in the learning process

Learning media that are generally used in the learning process at SMP Darul Arqam Makassar include: (a) computer software or files, (b) learning videos or films, (c) internet, and (d) educational aids.

\section{Active and creative learning}

Teachers' difficulties in implementing active and creative learning at SMP Darul Arqam Makassar include: (a) not enough time and (b) lack of mastery of effective and efficient teaching methods. The supporting factors for teachers in implementing active and creative learning include: (a) the support of the Principal, (b) the adequacy of supporting facilities and infrastructure in schools, (c) the ability of students (input), which is quite adequate.

6. The end of the learning activities

The final learning activities include things that the teacher does when closing the learning activities and the activities carried out by the teacher to improve the learning process in order to improve the competence of students including: (a) together with students reflecting or evaluating their investigations, (b) together students evaluate the entire series of learning activities and the results obtained, (c) reward the efforts or learning outcomes of individuals and groups, (d) help students find direct or indirect benefits from the learning outcomes that have taken place, ( e) evaluate the learning process and results, (f) provide feedback on the learning process and results, (g) carry out follow-up activities in the form of giving assignments, both individual and group assignments, (h) informing the learning activity plan for the next meeting, (i) ending the learning process according to I with the scheduled time, and (j) invite to pray together.

The activities carried out by teachers to improve the learning process in order to improve the competence of students include: (a) remedial for students who have not finished studying, (b) enrichment for students who have finished studying first, (c) reflect on the learning process and improve learning, (d) analyze students' absorption and improve learning, (e) check students' learning styles and adjust learning, (f) communicate with colleagues at the Subject Teacher Conference (MGMP) to better learning.

7. Assessment of learning processes and outcomes

The design of the assessment of learning processes and outcomes in learning quality management is based on the Regulation of the Minister of Education and Culture 
no. 22 of 2016 concerning Standards for Primary and Secondary Education in Chapter V regarding the assessment of learning processes and outcomes.

Based on document 1 KTSP SMP Darul Arqam TA 2020/2021 on pages 164-189, it is known that the assessment system used by educators and education units in measuring the achievement of learning processes and outcomes in the realm of attitudes, knowledge, and skills. In addition, it is also known the requirements for class promotion and graduation for Makassar students.

The same thing was also stated by the Principal of SMP Darul Arqam regarding the learning outcomes assessment system that:

"Assessment of learning outcomes by educators at SMP Darul Arqam is carried out to fulfil formative and summative functions in the form of daily assessments and mid-semester assessments. Mid-semester assessment is an assessment carried out by educators whose scope of material consists of several Basic Competencies and the technical implementation is left to educators. Only in the education unit the implementation time has been determined." 25

Furthermore, the Principal of SMP Darul Arqam said that:

"Daily assessments can be in the form of tests, observations, assignments, or other necessary forms that are used to measure and determine the achievement of student competencies, establish improvement or enrichment programs based on the level of competency mastery, improve the learning process, and prepare reports on the progress of learning outcomes. "26

The report on the results of the attitude assessment by the educator is submitted in the form of a predicate (very good, good, sufficient, or less) and is equipped with a description. Knowledge and skills assessment reports in the form of numbers (0-100), predicates (A, B, C, or D), and descriptions.

In addition, the assessment of learning outcomes by educators at Darul Arqam Middle School is also in the form of a final assessment, namely activities carried out to measure the achievement of student competencies at the end of the semester and/or the end of the year, while school exams are activities carried out to measure the achievement of student competencies as a recognition of learning achievement and/or completion of an educational unit. The coverage of the end-of-semester assessment is all indicators that represent $\mathrm{KD}$ in the odd semester, while the material coverage of the end-of-year assessment includes all indicators that represent KD in the even semester. School exam materials include KD which represents the achievement of SKL.

The attitude assessment technique used at SMP Darul Arqam Makassar can be seen in the following schematic image.

${ }^{25}$ Interview with the Principal at SMP Darul Arqam Makassar. On July 10, 2021

${ }^{26}$ Interview with the Principal at SMP Darul Arqam Makassar. On July 10, 2021 


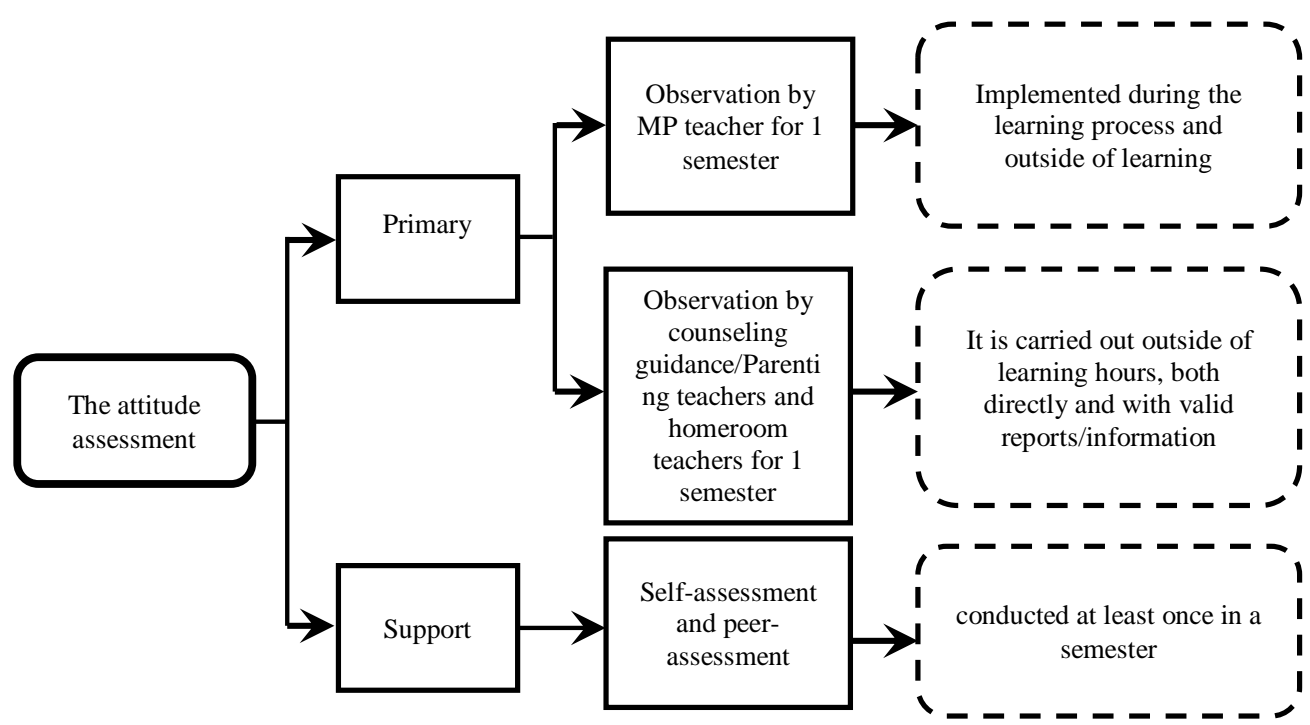

Figure 4.2. Attitude Assessment Technique Scheme

(Source: Documen 1 KTSP SMP Darul Arqam 2020/2021)

The results of the attitude assessment for one semester are reported in the form of predicates (very good, good, sufficient, or less) and descriptions that describe students' behaviour. The attitude assessment was carried out by all subject teachers, coaches, and homeroom teachers, as well as residents of the Islamic Boarding School where Darul Arqam Middle School is located

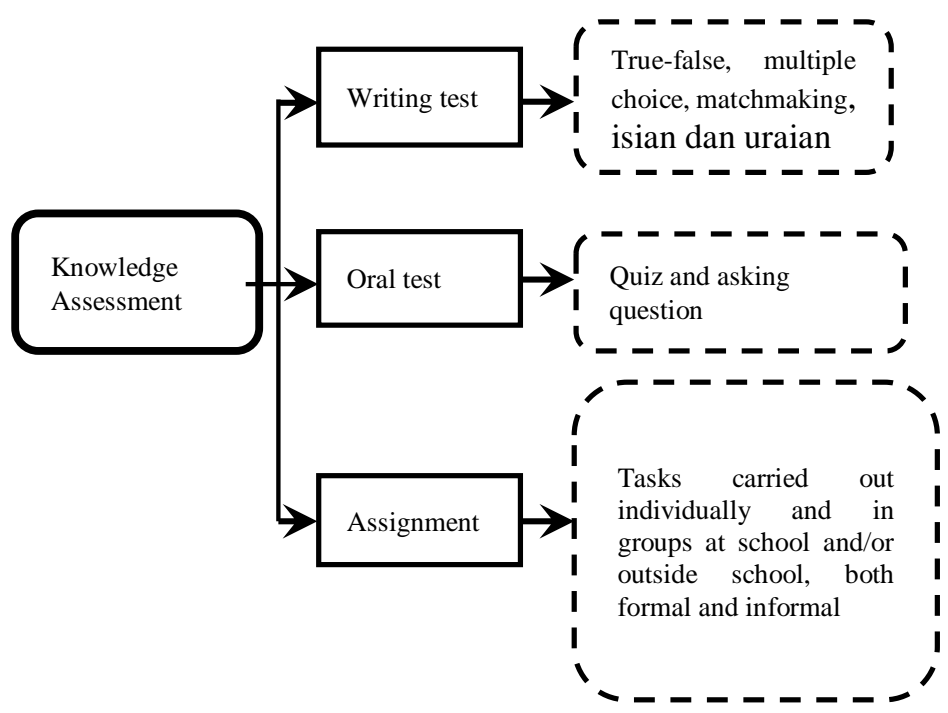

Figure 4.3. Knowledge Assessment Technique Scheme

(Source: Documen 1 KTSP SMP Darul Arqam TA. 2020/2021)

Knowledge assessment is carried out with various assessment techniques that are adapted to the characteristics of the competencies being assessed. The techniques commonly used are written tests, oral tests, and assignments. The knowledge assessment scheme can be seen in the following figure.

Skills assessment techniques can be carried out using various techniques, including: practice/performance assessment, projects, portfolios, or products. The skill assessment scheme can be seen in the following figure. 


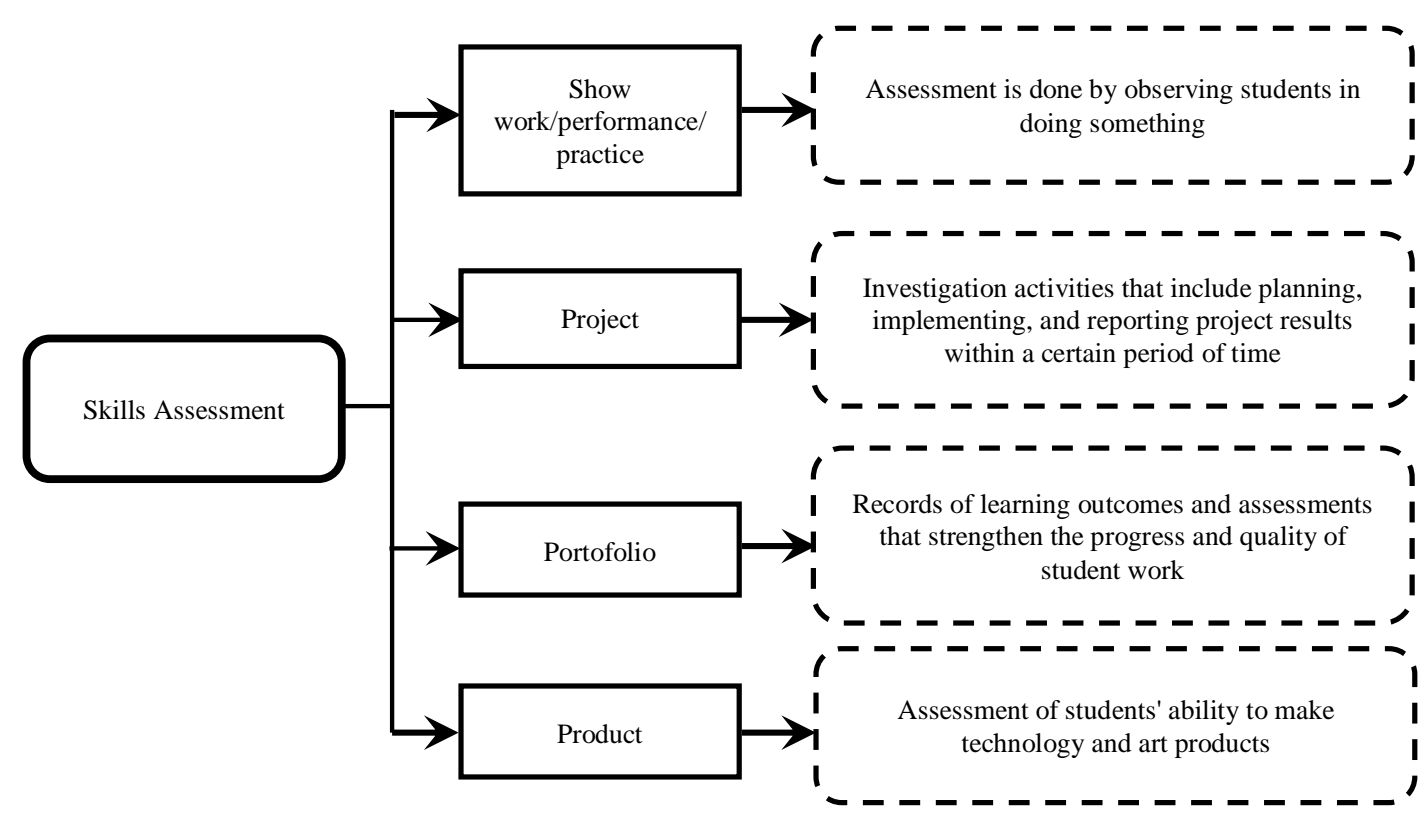

Figure 4.4. Skema Teknik Penilaian Keterampilan

(Source: Dokumen 1 KTSP SMP Darul Arqam TA. 2020/2021)

\section{Learning supervision}

The design of the learning supervision process is carried out through monitoring, supervision, evaluation, reporting, and follow-up activities on a regular and continuous basis, so the items that describe learning supervision at SMP Darul Arqam Makassar are described as follows:

\section{Supervision principle}

Supervision is carried out with objective and transparent principles at SMP Darul Arqam Makassar by using an instrument to assess teachers and employees' performance for monthly, semester, and yearly periods.

Researchers found documents in the form of attendance lists of teachers and employees as well as journals of teaching activities for teachers and employees which were validated by the Principal and Deputy Mudir 1 for Education. The same thing was stated by the Principal of SMP Darul Arqam that:

"In terms of monitoring the performance of teachers and employees, we are objective and transparent. It is said to be objective because we have monthly, semester and yearly performance appraisal instruments. It is transparent because the recapitulation of the attendance list of teachers and employees is validated by the Principal by matching it on the teacher's attendance list in the classroom and in the administration room and also validated by the finance staff by checking with the teacher or employee concerned before the list of monthly honorarium applications is submitted. and approved by the Mudir of Darul Arqam Islamic Boarding School Makassar. "27

2. Implementing supervision

Internal supervision at SMP Darul Arqam Makassar is carried out by the Principal

${ }^{27}$ Interview with the Principal at SMP Darul Arqam Makassar. On July 10, 2021 
and Supervisory Supervisor by examining the RPP once a semester. Prior to the visit of the school superintendent, the Principal first instructs the teachers to prepare the RPP and conducts an examination of the RPP that has been prepared by the teacher. In addition to examining the RPP at the beginning of the semester, the Principal and Supervisor also supervise. However, the Principal performs academic supervision of the teachers, while the Supervisory Supervisor carries out managerial supervision.

"The Principal and Supervisory Supervisor carry out internal supervision at SMP Darul Arqam Makassar by examining the Lesson plan once a semester. Prior to the visit of the school superintendent, the Principal first instructs the teachers to prepare the RPP and conducts an examination of the RPP that the teacher has prepared. In addition to examining the RPP at the beginning of the semester, the Principal and Supervisor also supervise. However, the Principal performs academic supervision of the teachers, while the Supervisory Supervisor carries out managerial supervision. " 28

\section{Supervision process}

The supervision process at SMP Darul Arqam Makassar is not only during the implementation of learning but starts from the planning stage to the assessment of learning outcomes. The results of the interview with the Principal also revealed that:

"The learning process is supervised at the planning, implementation, and assessment stages of learning outcomes. Prior to the preparation of learning tools, it had become a routine agenda at Islamic Boarding Schools to conduct workshops and training which was attended by all educational units, not only teachers and coaches who teach at Darul Arqam Middle School but all other educational units and the materials were adjusted to what the teachers and coaches needed in the implementation of the learning process. Preparation of learning tools and student development. Meanwhile, during the implementation of learning, academic and managerial supervision is carried out, in which the supervisor usually observes several teachers teaching in the classroom. The supervisor's final session of the visitation visit is generally collected in the 2nd floor Mini Hall for consultation, discussion, and giving examples of learning in class. ${ }^{29}$

Based on the findings and description of the learning quality management components of SMP Darul Arqam Makassar above, it can be seen in Table 4.7 as follows.

\section{CLOSING}

Based on the results of the study, the researchers concluded that learning planning was divided into several items including: curriculum tools (KTSP) that were socialized, school directions and policies, stakeholder involvement in its preparation, had national content and school-specific content in the KTSP, educational calendar, annual program , semester program, syllabus, material development and preparation of lesson plans. In Organizing there are items for the division of teaching and additional tasks, preparation of learning activity schedules, remedial and enrichment schedules, extracurricular schedules and guidance and counseling schedules. In holding the implementation, the

${ }^{28}$ Interview with the Principal at SMP Darul Arqam Makassar. On July 10, 2021

${ }^{29}$ Interview with the Principal at SMP Darul Arqam Makassar. On July 10, 2021 
items that need to be considered are the opening of learning at the beginning of the new semester/school year, teacher activities at the beginning of learning and activities carried out by students, activities carried out by teachers in learning and learning activities carried out by students, media and learning facilities, learning active and creative, the final learning activities include what the teacher does when closing and the activities the teacher does to improve the learning process, and the assessment of learning processes and outcomes. At the supervisory stage, several things need to be considered, namely monitoring the performance of teachers and employees with objective and transparent principles, supervision is carried out by the Principal, Supervising Supervisor, Council for Education and Culture and LP2M PWM Sul-Sel and supervision is carried out from planning to the process of assessing learning outcomes.

\section{REFERENCES}

Aqib, Zainal. 2013. Model-model, Media dan Strategi Pembelajaran Kontekstual (Inovatif). Bandung: Yrama Widya.

Badaruddin. 2013. Dasar-Dasar Manajemen. Yogyakarta: Alfabeta.

Bafadal, Ibrahim. 2009. Manajemen Peningkatan Mutu Sekolah Dasar; Dari Sentralisasi Menuju Desentralisasi. Jakarta: Bumi Aksara.

Engkoswara dan Komariah. 2010. Administrasi Pendidikan. Bandung: Alfabeta.

Feriyanto, dkk. 2015. Pengantar Manajemen (3 in 1) untuk Mahasiswa dan Umum. Yogyakarta: Mediatera.

Muljono, P. 2006. Standar Proses Pembelajaran. Jakarta. Buletin BSNP Volume 1/No. 2/ Mei 2006.

Notoatmodjo, Soekidjo. 2009. Pengembangan Manajemen Sumber Daya Manusia. Jakarta: PT. Rineka Cipta.

Sutikno, M. Sobry. 2009. Belajar dan Pembelajaran. Bandung: Prospect.

Suyono dan Hariyanto, 2011. Belajar dan Pembelajaran. Bandung: PT Remaja Rosdakarya.

Trianto. 2010. Model Pembelajaran Terpadu, Konsep, Strategi dan Implementasinya dalam KTSP. Jakarta: Bumi Aksara.

Usman, Husaini. 2011. Manajemen; Teori, Praktik, dan Riset Pendidikan Edisi 3. Cetakan ketiga. Jakarta: Bumi Aksara.

\section{DATA WAWANCARA}

Wawancara dengan Kepala Sekolah di SMP Darul Arqam Makassar. Pada tanggal 10 Juli 2021.

Wawancara dengan Wakil Kepala Sekolah di SMP Darul Arqam Makassar. Pada tanggal 17 Juli 2021.

Wawancara dengan Guru di SMP Darul Arqam Makassar. Pada tanggal 17 Juli 2021. 